ISSN 1991-8631

Original paper

http://indexmedicus.afro.who.int

\title{
Light fraction of organic matter under different land management systems in a Nigerian derived savanna soil
}

\author{
A. M. ADURADOLA ${ }^{1}$, A.O. OLADOYE ${ }^{1 *}$ and B.S. BADA ${ }^{2}$ \\ ${ }^{I}$ Department of Forestry and Wildlife Management, Federal University of Agriculture, Abeokuta, Nigeria. \\ ${ }^{2}$ Department of Environmental Management and Toxicology, Federal University of Agriculture, Abeokuta, \\ Nigeria. \\ *Corresponding author, E-mail: segun11us@yahoo.com
}

\begin{abstract}
This study determined the influence of land management practices on the light fraction of soil organic matter in a derived savanna ecosystem. Soil samples were collected from Tectona grandis, Eucalyptus camadulensis, Musa paradisiaca plantations and the Natural forest in the Institute of Food Security, Environmental Resources and Agricultural Research (IFSERAR) farm, Federal University of Agriculture, Abeokuta, Nigeria. Soil samples were collected randomly under each land practices at 0-10 $\mathrm{cm}$ and $10-15 \mathrm{~cm}$ depths. Microbial identification, total heterotrophic (THC), light fraction organic matter (LFOM) were determined. Data obtained were subjected to descriptive statistics, ANOVA, and correlation analysis, means were separated using Duncan Multiple range Test. Actinomycetes, Bacillus enterobacter, Staphylococcus, Flavobacterium, Escherichia coli, Serratia, Aspergillus niger, Fusarium spp, Penicillum spp and Aspergillus flavis were identified in the four land management practices. Significantly $(\mathrm{P}<0.05)$ highest THC was observed in the Musa paradisiaca plantation while Euclayptus had the least. Significantly $(\mathrm{p}<0.05)$ higher LFOM was observed in plantain and teak plantation. There was positive correlation between THC and LFOM. Conclusive, the study revealed that light fraction contents provide a sensitive and reasonably precise measure of organic matter indices.
\end{abstract}

(C) 2013 International Formulae Group. All rights reserved.

Keywords: light fraction, organic matter, management system, derived savanna.

\section{INTRODUCTION}

Light fraction organic matter generally accounts for 0.1 to $0.3 \%$ of the total weight of cultivated soils, but grassland and forest soils and podzols with relatively slow decomposition rates may contain considerably higher percentages (3 to 10\%). Light fraction organic matter is enriched in carbon and nitrogen, relative to fractions dominated by mineral constituents; consequently, the proportion of total soil organic $\mathrm{C}$ and $\mathrm{N}$ that is present as the light fraction may reach 40 and $30 \%$ respectively (Kanazawa and Filip, 1986). Light fraction organic matter comprising of plant residues contains high concentrations of oligosaccharides, polysaccharides and hemicelluloses and thus serves as a readily decomposable substrate for microorganisms in 
soil, More than half the microbial populations and enzyme activities may be associated with the light fraction (Kanazawa and Filip 1986, Lavelle et al., 1992, Lavelle et al., 1997; Barthès et al., 1999). The organic matter in this fraction decomposes quickly, despite a wide $\mathrm{C} / \mathrm{N}$ ratio (Collins et al, 1984; Ford, 1964).

Studies with isotopic traces indicate that the light fraction organic matter has a faster turnover rate than other physical fractions but may consist of two or more carbon pools with different turnover rates (Bonde et al., 1992). Light fraction organic matter has been shown to be a useful indicator of soil quality and in particular, may be sensitive to changes in labile organic matter. The light fraction contents of soils is strongly correlated to bacteria population suggesting that the light fraction may be an important carbon and energy source for microorganisms. Because the light fraction is not protected by clay minerals, it is readily accessible to microbial and enzyme activity. Furthermore, the light fraction is believed to be comprised of relatively labile constituents, such as carbohydrates, which would further enhance its susceptibility to microbial attack. Hence, the need to carry out the experiment on light fraction organic matter in soil from different land management systems. The objectives of this study are to determine the influence of land management practices on the light fraction of soil organic matter and to evaluate its sensitivity as an indicator of changes in labile organic matter.

\section{MATERIALS AND METHODS}

\section{Study site}

The study was carried out in the Institute of Food Security, Environmental
Resources and Agricultural Research (IFSERAR) farm, Federal University of Agriculture, Abeokuta. The site between latitudes $7^{0}$ and $7^{0} \quad 58^{1} \mathrm{~N}$ and between longitude $3^{0} 2^{1} \mathrm{E}$ and $20^{0} 37^{1}$, at $600 \mathrm{~m}$ above sea level. The general topography of the site is undulating land terrain while local topography is upper mid-slope. Original vegetation is derived savanna zone.

Soil is under laid by the pre-cambian metamorphic rocks of the basement complex (Jones and Hockey, 1964) with bed rock consisting predominantly of granite gneisses, bounded biotite horn blende gneises, quartrite and quarz schists. The soil is sandy loam, very dark in colour at the top surface and greyish brown $(5 \mathrm{Y} 5 / 1)$ in the subsoil. The area has a tropical climate with a bimodal distribution of rainfall. It lies within the humid lowland region (Keay, 1953) with two distinct seasons. The wet season extends from April to October while the dry season extends from November to March. The mean annual rainfall is $1113.1 \mathrm{~mm}$. The bimodal distribution of rainfall has its peaks in July and September and break in August. Generally, the rainfall could be heavy and erosive and sometimes accompanied by lightening and thunderstorms at the beginning and the end of the rainy season. The mean monthly temperature varies from $22.74{ }^{\circ} \mathrm{C}$ in August to $36.32{ }^{\circ} \mathrm{C}$ in March. The relative humidity is high ranging from $75.52 \%$ in February to $88.15 \%$ in July (Aiboni, 2001).

\section{Soil sample collection}

Soil samples were collected under Tectona grandis, Eucalyptus camadulensis and Plantain plantations and natural regrowth forest in the IFSERAR sites, in the Federal University of Agriculture Abeokuta . In each 
of these management sites, five auger points were made at equidistance location diagonally across the plot at $0-10 \mathrm{~cm}$ and $10-15 \mathrm{~cm}$ depth. The five auger samples were bulked per plot at each depth. Sub samples were taken from the bulked samples to make three replicates at each depth per site giving a total of $30 \mathrm{sub}$ samples.

\section{Isolation and analysis of light fraction}

The air dry soil samples were sieved and plant residues retained on the sieve were discarded. Approximately $10 \mathrm{~g}$ of each sample was weighed into $100 \mathrm{ml}$ beaker. After adding $40 \mathrm{ml}$ of sodium iodide solution, the suspension was dispersed for 30 seconds using a Virtis homogenizer. The beakers was then covered and the suspension was allowed to equilibrate for 48 hours at room temperature. The suspended light fraction material was removed using a vacuum and transferred directly to a millipure filtration unit with Whatman no.1 paper. The light fraction was washed under suction with three successive aliquots of $0.01 \mathrm{~m} \mathrm{CaCl}_{2}$ and three aliquots of distilled water. After drying overnight (approximately 17 hours at $70{ }^{\circ} \mathrm{C}$ ), the light fraction (LF) was scraped from the filter paper and weighed (Oyun, 2004).

Soil samples and the LF were finely ground $(<250 \mathrm{~m})$ and analyzed for total carbon and nitrogen contents. The $\mathrm{N}$ content was determined by Kjeldahl method while organic carbon by dichromate wet oxidation method (Black, 1965; Bremner, 1965).

\section{Determination of microbial population}

The soil samples were immediately analyzed on getting into the laboratory for the Total Heterotrophic Count (THC) and some other selected bacterial flora.
One gram of the soil samples was weighed and dispensed into $10 \mathrm{ml}$ sterile distilled water to serve as the stock from which the ten-fold serial dilution was carried out. These were plated out on Nutrient Agar for the Total Heterotrophic Count (THC); Eosin Methylene Blue, for Escherichia coli and other Enterics and Potato Dextrose Agar, for the Fungal isolates, using the pour plate technique of Harrigan and MacCance (1966). The Nutrient Agar and the Eosin Methylene Blue plates were incubated at $37{ }^{\circ} \mathrm{C}$ for 48 hours while the Potato Dextrose Agar plates were incubated at the same temperature for 72 hours inside the incubator.

After the incubation period, the number of colonies which developed were counted and recorded in colony forming unit per gram (cfu/g). The average of the duplicate growth was recorded.

\section{Data analysis}

The statistical analysis of the data was conducted using the General Linear Model of SAS software (SAS Institute, Inc., 1989). ANOVA and Duncan's Multiple Range Test were used to separate the means. Correlation analysis was also carried out to examine if relationship exist between the light fraction (LF) characteristics and other indices of labile organic matter in the soil samples

\section{RESULTS}

\section{Identification of microorganism}

Actinomycetes, Bacillus enterobacter, Staphylococcus, Flavobacterium, Escherichia coli, Serratia, Aspergillus niger, Fusarium spp, Penicillum spp and Aspergillus flavis were identified in the four plantations.

Significantly $(\mathrm{p}<0.05)$ highest Total Heterotrophic Count (THC) was observed in 
the plantain plantation while Eucalyptus had the least (Table 1). Significantly $(\mathrm{p}<0.05)$ higher Eosin Methylene Blue (EMB), Light fraction nitrogen (LFN), Light fraction organic carbon (LFC) and Light fraction organic matter (LFOM) were observed in natural plantation followed by Teak Plantation, Eucalyptus plantation had the lowest EMB while plantain plantation had the lowest LFN, LFC, and LFOM (Table 1). There was no significant difference in the values of THC between natural and teak plantation. Similar trend was observed in LFC and LFOM both between plantain and
Eucalyptus plantations.

On the effect of depth, LFOM (0.13), EMB (50.25) and THC (305.00) were significant higher in $0-15 \mathrm{~cm}$ depth at $\mathrm{p}>0.05$, while LFC (1.50) and LFN (0.18) were significant in $0-10 \mathrm{~cm}$ (Table 2).

THC was significantly positively correlated $(\mathrm{p}<0.01)$ with EMB. The correlation between THC and LFN; LFC and LFOM was positive but not significant (Table 3). LFC was significantly positively correlated with $\operatorname{EMB}\left(.627^{* *}\right)$ and $\operatorname{LFN}(.707 * *)$ at $(\mathrm{p}>0.01)$. LFOM was poorly correlated with other parameters measured (Table 3 ).

Table 1: Influence of land management on total heterotrophic count. Eosin Methylene Blue and soil light fractions.

\begin{tabular}{lccccc}
\hline Land Mgt & THC/cfu/g & EMB/ cfu/g & LFN/g/kg & LFC/ g/kg & LFOM/g/kg \\
\hline Plantain & $314.0 \mathrm{a}$ & $30.0 \mathrm{c}$ & $0.130 \mathrm{c}$ & $0.606 \mathrm{~d}$ & $0.115 \mathrm{a}$ \\
Plantation & & & & & \\
Natural Forest & $298.0 \mathrm{~b}$ & $67.0 \mathrm{a}$ & $0.217 \mathrm{a}$ & $1.698 \mathrm{a}$ & $0.107 \mathrm{~b}$ \\
Teak & $290.0 \mathrm{~b}$ & $49.5 \mathrm{~b}$ & $0.168 \mathrm{~b}$ & $1.600 \mathrm{~b}$ & $0.138 \mathrm{a}$ \\
Eucalyptus & $246.0 \mathrm{c}$ & $18.0 \mathrm{~d}$ & $0.132 \mathrm{c}$ & $0.902 \mathrm{c}$ & $0.093 \mathrm{~b}$ \\
& & & & &
\end{tabular}

Means in the same column followed by the same superscript are not significantly $(\mathrm{p}<0.05)$ different according to DMR test.

$\mathrm{THC}=$ Total Heterotrophic Count

$\mathrm{EMB}=$ Eosin Methylene Blue

LFN = Light Fraction Nitrogen

LFC $=$ Light Fraction Organic Carbon

LFOM = Light Fraction Organic Matter

Table 2: Effect of soil depth on total heterotrophic count, Eosin Methylene Blue and soil light fractions.

\begin{tabular}{lcc}
\hline & $\mathbf{0 - 1 0}$ & $\mathbf{1 5 - 3 0}$ \\
\hline THC & $269.00 \mathrm{~b}$ & $305.00 \mathrm{a}$ \\
EMB & $32.00 \mathrm{~b}$ & $50.25 \mathrm{a}$ \\
LFN & $0.18 \mathrm{a}$ & $0.14 \mathrm{~b}$ \\
LFC & $1.50 \mathrm{a}$ & $0.90 \mathrm{~b}$ \\
LFOM & $0.09 \mathrm{~b}$ & $0.13 \mathrm{a}$ \\
\hline
\end{tabular}

Means in the same row followed by the same superscript are not significant $(\mathrm{p}<0.05)$ different according to DMR test. 
Table 3: Correlation coefficients for the relationship between THC, EMB, LFN, LFC and LFOM.

\begin{tabular}{lccccc}
\hline & THC & EMB & LFN & LFC & LFOM \\
\hline THC & - & & & & \\
EMB & $.640^{* *}$ & - & & & \\
LFN & .123 & .334 & - & & \\
LFC & .037 & $.627^{* *}$ & $.707^{* *}$ & - & $\mathbf{- . 2 7 8}$ \\
LFOM & .329 & -.034 & -.289 & -.278 & - \\
\hline Correlation is significant at the 0.01 level. & & & &
\end{tabular}

Correlation is significant at the 0.01 level.

\section{DISCUSSION}

Result showed significantly $(\mathrm{p}<0.05)$ highest EMB, LFN, LFC in natural plantation followed by Teak, Eucalyptus and plantain plantations. This might be due to the variation in the degree of tillage practices. Maximum tillage carried out in plantain and Eucalyptus expose the soil organic matter to high rate of degradation/depletion. The positive correlation coefficient between organic matter and nitrogen might be due to the source of nitrogen which is likely to be soil organic matter; Adetunji (2005) explained that organic matter is probably the most vital indication of soil quality and influences the physical, chemical and biological properties of soil quality and soil nitrogen is inextricably tied to the soil organic matter content because the bulk of soil nitrogen is in organic combination. High LFC, LFN and LFOM in the natural forest may be due to the composition of the forest litters which contains various tree species that have the potentials to fix nitrogen and other elements to the soil which could also be responsible for high microbial population. High THC in all the various land management assessed probably reflects the distribution of plants and microbial debris within the soil surface as reflected in the findings of Doran and Parkin (1994), Abawi and Widmer (2000) and Oladoye et al. (2011). Higher THC is an indication of increase in soil carbon content especially at the $0-10 \mathrm{~cm}$ depth. The differences in light fraction contents among the land management systems of various sites can be attributed to either the amount of residue or the rate of substrate decomposition. Differences in light fraction contents among the management systems may also indicate variations in environmental factors such as moisture and temperature which strongly influence decomposition (Oyun, 2004). Light fraction organic matter in the soil was significantly correlated to microbial population, this suggests that the light fraction is an important Carbon and energy source for soil micro-organisms since it is readily accessible to microbial and enzyme activity.

LFN, LFC and LFOM decrease significantly $(p<0.05)$ across the two soil depths, this observation is consistent with Atayese et al. (1993) who reported that soil organic matter and nitrogen decreased along the soil depth.

A direct effect of this biological activity is seen in the macro structure through the formation of soil pores as a consequence of faunal activity, root and fungal growth (Zech et al., 1997; Craswell and Lefroy, 2001) Overall; the study revealed that light fraction contents provide a sensitive and reasonably precise measure of organic matter indices.

\section{ACKNOWLEDGEMENTS}

The authors wishes to acknowledge the financial support of Institute of Food Security, Environmental Resources and Agricultural 
Research (IFSERAR), Federal University of Agriculture, Abeokuta, Nigeria.

\section{REFERENCES}

Abawi, GS, Widmer TL. 2000. Impact of soil health management practices on soil Borne pathogens, nematodes and root diseases of vegetables crops. Applied Soil Ecology, 15: 37-47.

Adetunji MT. 2005. Soil quality for ecological security and sustainable agriculture. Inaugural lecture series No. 19 of University of Agriculture, Abeokuta, Nigeria, pp 6-31.

Aiboni VU. 2001. Characteristics and Classification of soil of a representative topographical location in University of Agric. Abeokuta. Asset series A, 1(1): 51-61.

Atayese MO, Awotoye OO, Osonubi O, Mulongoy K. 1993. Comparison of the influence of resicular-arbuscular mycorrhizal on the productivity of hedgerow woody legumes and cassava at the top and the base of a hillslope in alley cropping systems. Biology and Fertility of Soils, 16: 198-204.

Barthès B, Albrecht A, Asseline J, De Noni G, Roose E. 1999. Relationships between soil erodibility and topsoil aggregate stability of carbon content in a cultivated Mediterranean highland (Avey ron, France). Communication in Soil Science and Plant Analysis, 30(13-14): 19291938.

Black CA. 1965. Methods of Soil Analysis Agronomy ( $\mathrm{N}^{\circ} 9$ Part 2). America Society of Agronomy: Madison Wisconsin.

Bonde TA, Christensen BT, Cerri CC. 1992. Dynamics of soil organic matter as reflected by natural $13 \mathrm{C}$ abundance in particle size fractions of a forested and cultivated oxisols. Soil Biol. Biochem.,
24: $275-277$.

Bremner JM. 1965. Total nitrogen. In Methods of Soil Analysis (Part 2), Black CA (ed). America Society of Agronomy: Medison.

Collins HP, Paul EA, Paustain K, Elliot ET. 1997. Characterization of soil organic carbon relative to its stability and turnover. In Soil Organic Matter in Temperate Agroecosystems, Paul EA, Elliot ET, Paustain K, Cole CV (eds). CRC Press, Inc.: Boca Raton. FL; 51-72.

Craswell ET, Lefroy RDB. 2001. The role and function of organic matter in tropical soils. Nutrient Cycling in Agroecosystems, 61(1-2): 7-18.

Doran JW, Parkin TB. 1994. Defining and assessing soil quality. In Defining Soil Quality for a Sustainable Environment, Doran JW et al. (eds). Soil Science Society of America Special Publication: Madison, Wisconsin; 3-21.

Ford SK. 1964. Nitrate fluctuations in tropical soils. Journal Agricultural Science, 50: 82-92.

Harrigane WF, Mccance ME. 1966. Laboratory Methods in Microbiology Academic Press London: New York; 342.

Jones HA, Hockey RD. 1964. Geology of parts of Southwestern Nigeria. Bulletin of Geology Survey, Nigeria. No. 31.

Kanazawa S, Filip Z. 1986. Distribution of microorganism, total bromas, and enzyme activities in different particles of brown soil. Microbial Ecol., 12: 205-215

Lavelle P, Blanchart E, Martin A, Spain A, Martin S. 1992. Impact of soil fauna on the properties of soils in the humid tropics. In Myths and Sciences of Soils in the Tropics $\mathrm{N}^{\circ} 29$, Soil Science Society of America: Madison, Wisconsin; 157-185.

Lavelle P, Bignell D, Lepage M, Wolters V, Roger $\mathrm{P}$, Ineson $\mathrm{P}$, Heal OW, Dhillion $\mathrm{S}$. 
1997. Soil function in changing world: the role of invertebrate ecosystem engineers. European Journal Soil Biolology, 33(4): 159-193.

Oladoye AO, Aduradola AM, Bada BS. Kudaisi BO. 2011. Light fraction of soil organic matter under different management systems in Abeokuta, a Derived Savanna, Nigeria. Journal of Agriculture, Forestry and Social Sciences 9(1): 143-148.

Oyun MB. 2004. Light fraction organic matter in soil from different management systems. Nigerian Journal of Soil Science, 14: 77-80.

SAS Institute, Inc. 1989. SAS/STATS users guide, Version $6,4^{\text {th }}$ ed. SAS Institute., Cary, NC.

Zech W, Senesi N, Guggenberger G, Kaiser K, Lehmann J, Miano TM. 1997. Factors

Controlling humification and mineralization of soil organic matter in the tropics. Geoderma, 79: 117-161. 